\title{
World Forestry Congress
}

\section{1-28 September 2003, Québec City, Canada}

The organizing committee of the XII World Forestry Congress is currently working on a set of themes that link forests and communities. These themes will bring the concept of harmony to the fore, serving as a focal point for all the discussions and reaching out, worldwide, to as many forestry stakeholders as possible.

The theme will be dealt with from four main components relating to targeted forest issues.

- State of the forests: trends and outlook

- Needs, values and aspirations

- Decisions made and present and future actions

- The future: a vision for the coming decades

Forests and Communities in Harmony is intended to provide an ideal opportunity for discussions on the unique universe that forests represent. These themes will endeavour to show that people (specialists, foresters, ecologists, workers, sil- viculture experts, farmers, craftspeople and citizens) from all walks of life play a primary role in the decision-making and the activities that shape the forests of today and tomorrow.

People are also the reason we need to take a closer look at forests; their management must serve to sustain societies and communities at the local, regional and international levels.

The Congress is open to all individuals, whether they are foresters or not, to men and women of all ages and to members of Aboriginal communities, as well as those who have recently demonstrated interest in the forestry community. It will address the concerns of all those interested in the future of all the forests of the world, including tropical, temperate, boreal, virgin forests, and those that are managed with various techniques, whether they are in plantations or being restored.

The focus will be on human factors given that the environment, the economy, society and culture must be viewed as an indivisible whole in efforts to ensure the sustainable development of forest ecosystems.

As the first forestry congress of the thirdmillennium, the XII World Forestry Congress 2003 will provide an opportunity for the international forestry community to gather and to develop a vision to orient actions over the coming decades. All those who are dedicated to the sustainable development of forests are invited to attend this key event.

Contact:

Secretariat General

XII World Forestry Congress 2003

P.O. Box 7275

Québec City, Canada

GIG $5 E 5$

E-mail:sec-gen@wfc2003.org URL: www.wfc.2003.org

\section{Global Information Networks - Canadian Contributions}

Canada participates in a number of international fora that support global sustainability. Following are some examples. - Canada participates in joint information gathering and sharing related to energy with the International Energy Agency, the Nuclear Energy Agency, the Hemispheric Energy Initiative, and the Energy Working Group of the AsiaPacific Economic Cooperation.

- Natural Resources Canada's Canada Centre for Remote Sensing is establishing a UNEP Global Resource Information Database site to archive, disseminate, and provide tools for integrating geospatial databases derived largely from remotely sensed imagery.

- Canada promotes the sustainable development of minerals and metals through regional and intergovernmental networks such as the hemispheric Mines Ministries of the Americas (CAMMA); the Asia-Pacific Economic Cooperation Expert Group on Minerals and Energy Exploration and Development; the inter- national study groups on copper, nickel, and lead and zinc; and the recently established Non-ferrous Metals Consultative Forum on Sustainable Development.

- Within the World Climate Research Programme, Canadian scientists participate in several large-scale international climate studies. As a member of the World Meteorological Organization, Canada maintains a monitoring network that contributes to the Global Climate Observing System and the World Weather Watch. Environment Canada maintains the World Ozone and Ultraviolet Radiation Data Centre.
- Environment Canada manages a centre at the National Water Research Institute to support the Global Environment Monitoring System for water (GEMS/Water) under the United Nations Environment Programme.

- Canada hosts the Canadian Biodiversity Information Network, a national node in the United Nations Convention on Biological Diversity Clearing-house Mechanism, a global system of Internet-based databases that, among other things, helps build capacity to achieve convention goals, including the sustainable use of biodiversity.
BOMBARDIER AEROSPACE

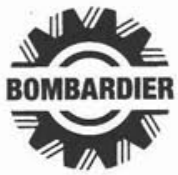

A CIF/IFC Corporate Sustaining Member 


\section{United Nations Forum on Forests}

\author{
Establishment of the UNFF and \\ its objectives \\ The United Nations Forum on For-
} est (UNFF) was established as a subsidiary body to Economic and Social Council of the United Nations (ECOSOC) in October 2000. It builds on the five-year $a d h o c$ process of Intergovernmental Panel on Forests (IPF) and Intergovernmental Forum on Forests (IFF). Exceptionally within the ECOSOC system, the UNFF has a universal membership i.e. it is open to all governments.

The main objective of the UNFF is to promote the management, conservation and sustainable development of all types of forests and to strengthen long-term political commitment to this end.

The UNFF was established in particular to facilitate the implementation of the actions agreed in the international forest policy deliberations since UNCED (1992). These actions include the Forest Principles and an extensive set of proposals for actions from the IPF/IFF process (1995-2000). The UNFF will take steps, as a matter of priority, towards financial support and technology transfer to enable the implementation of sustainable forest management in developing countries. It will also need to consider, towards the end of its initial five-year period, the development of a legal framework on all types of forests.

\section{First session of the UNFF, June 2001}

The UNFF had its organizational meeting in February 2001. Its first substantive session will be held on 11-22 June in New York. At this session, the UNFF will set the agenda for the global level forest policy deliberations for the next five years, as it will adopt its Multi-Year Programme of Work. Decisions will need to be made on, inter alia, thematic focuses for each session, monitoring, assessment and reporting on progress, organization of future multi-stakeholder dialogues and, very importantly, on timing of ministerial segments. Should UNFF decide to organise a ministerial level segment at UNFF 2, in 2002, the session would be held in San Jose, Costa Rica. Otherwise, UNFF 2 would meet in Geneva.

Another main focus at UNFF 1 will be the development of the UNFF Plan of Action, with financial provisions, for the implementation of the IPF/IFF proposals for action.

\section{Involvement of multiple stakeholders in UNFF}

ECOSOC decided that the UNFF would operate in a transparent and participatory manner. Governments have therefore encouraged wide participation of non-governmental organizations, the private sector and other interested stakeholders.

A way of receive inputs to the UNFF process from multiple stakeholders is to organise multi-stakeholder dialogues. During UNFF 1, a side event will be organised to provide an opportunity for all forest-relevant stakeholders to participate in an informal setting to share their views on the format, scope, goal and expected outcome of the UNFF multi-stakeholder dialogues, and to discuss how to make effective use of such dialogues during forthcoming UNFF sessions.

\section{Collaborative Partnership on Forests established to support the UNFF}

Closer coordination and cooperation among international organizations, particularly the UN organizations, has been called upon in various occasions. A step towards this goal was the recent establishment of the Collaborative Partnership on Forests (CPF). The CPF was founded in April 2001 by eight organizations (members of the former Interagency Task Force on Forests) to support the work of UNFF.

The CPF members include currently: Secretariat of the Convention on Biological Diversity (CBD), Centre for International Forestry Research (CIFOR), Department of Economic and Social Affairs of the United Nations Secretariat (DESA), Food and Agriculture Organization of the United Nations (FAO, Chair), International Tropical Timber Organization (ITTO), United Nations Development Programme (UNDP), United Nations Environment Programme (UNEP) and the World Bank. The CPF membership is expected to ultimately include about a dozen international forest-related institutions. Currently, the Secretariats of the Convention to Combat Desertification (CCD), Framework Convention on Climate Change (FCCC) and the Global Environmental Facility (GEF) have been invited to join the CPF.
The CPF is establishing a CPF Network to facilitate interaction and communication with a wide range of international and regional organizations, including NGOs, private sector entities and other major groups.

An open CPF-NGO meeting will be organised during UNFF 1 to exchange views on how to build effective collaboration between the CPF and NGOs in support of the work of the UNFF.

\section{Looking Forward}

The policy environment and focus in the international forest policy fora have changed significantly in the past decade. The five-year IPF/IFF process (1995-2000) helped to understand forests as a crosssectoral issue and providing multiple benefits to people, environment and economic. A trend may be emerging in international forest policy to further emphasize the role of forests in providing livelihoods, employment, income generation and subsistence, as well as alleviating poverty.

A variety of views flourish on the future of the UNFF process. One view is, however, common to all, that it is now time to move from dialogue to action. Therefore, the greatest challenge at UNFF 1 will most likely be the development of the UNFF Plan of Action, and engagement of all stakeholders - governments, CPF members, other international and regional organizations, institutions and instruments, as well as NGOs - in effective implementation of the IPF and IFF recommendations. Well designed UNFF Plan of Action, with clear targets and time tables would provide a strong message from the forest sector to Earth Summit 2002 (Johannesburg, South Africa, in September 2002).

Further information on UNFF is available on the website of the UNFF Secretariat at:

www.un.org/esa/sustdev/forests.htm

Tïna Vähänen

Forest Policy Advisor, UNFF Secretariat

E-mail:vahanen@un.org 


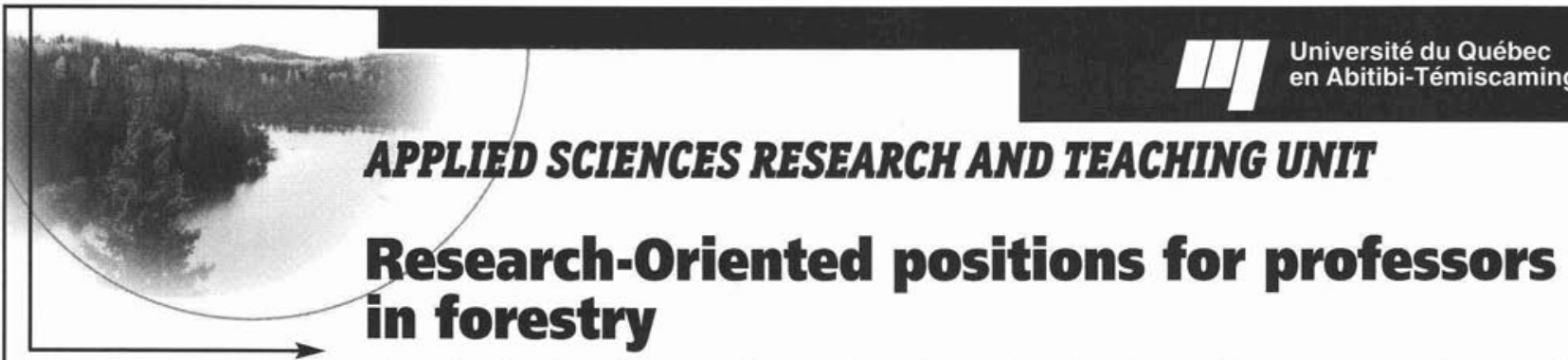

The Université du Québec en Abitibi-Témiscamingue (UQAT) wishes to fill four research-oriented positions for professors in forestry within the activities of its Applied Sciences Research and Teaching Unit. Candidates will join the research team of the NSERC UQAT-UQAM Industrial Chair in Sustainable Forest Management (http://web2.uqat.uquebec.ca/cafd) and the academic staff of the Applied Sciences Department of UQAT.

\section{1st Position: Professor in silviculture and forest management}

We are seeking a person with a Ph.D., with a specialisation in silviculture, in applied forest ecology or in forest management. We are particularly looking for a person who is able to develop silvicultural techniques and management scenarios based on an understanding of natural forest dynamics. Place of work: Rouyn-Noranda.

\section{$2^{\text {nd }}$ Position: Professor in intensive silviculture}

We are seeking a person with a Ph.D., with a specialisation in silviculture or in applied forest ecology. We are particularly looking for a person who is able to develop and test intensive silvicultural treatments adapted to small-scale forestry and who will address management priorities and operational constraints of an integrated intensive management strategy identified by partners. Place of work: Amos.

\section{$3^{\text {rd }}$ Position: Professor in wildlife management}

We are seeking a person with a Ph.D., with a specialisation in wildlife management or wildlife ecology. We are particularly looking for a person who is able to develop a research program on the effects of intensive silvicultural treatments on wildlife species in the context of integrated forest resource management. Place of work: Amos.

\section{$4^{\text {th }}$ Position: Professor in geomatics and/or remote sensing}

We are seeking a person with a Ph.D., with a specialisation in geomatics and/or remote sensing applied to forest resource management. We are particularly looking for a person who is able to participate in the development of GIS- and/or remote sensing-based decision support tools designed to improve planning and monitoring of sustainable forest management activities. Place of work: Rouyn-Noranda.

\section{For all positions}

We also expect a solid scientific production, a good working understanding of French, or the intention of acquiring such. A post-doctoral fellowship as well as experience in industry or government would be desirable but not essential. The selection committee will also consider candidates who are in the final phase of completing their Ph.D. theses.

The person selected will be expected to dedicate him or herself to research and development tasks within the activities of the NSERC-UQAT-UQAMM Industrial Chair in Sustainable Forest Management. The research-oriented professor will also contribute to a lesser extent to teaching and directing students enrolled in M.SC. and Ph.D. programs offered by the Applied Sciences Research and Development Unit.

The person will also be expected to accomplish administrative and technical transfer tasks and to be open to working in partnership with private companies and governmental organisations. He or she should be comfortable working in a region with a resource-based economy, and in a small university which includes contributing to the socio-economic development of the region as part of its mission.

In conformity with requirements concerning immigration to Canada, these positions are offered in priority to Canadian citizens and permanent residents.

\section{François Godard}

Directeur de l'Unité

d'enseignement et de recherche

en sciences appliquées

Université du Québec en

Abitibi-Témiscamingue

445, boul de l'Université

Rouyn-Noranda QC J9X 5E4

Fax: (819) 797-4727

\section{Positions begin : November 1, 2001}

Employment conditions : The position is open for an initial period of 3 years with the possibility of renewal. Employment conditions are defined by the collective agreement of the professors of the Université du Québec en AbitibiTémiscamingue. Place of work: Rouyn-Noranda.

Curriculum vitae with three letters of reference should be mailed by 4:30 PM, Friday, September 28, 2001. 


\section{Preparations under way for the International Year of Mountains 2002}

Despite their imposing presence, mountains are very fragile environments. The degradation of mountain environments affects nearly half of the world's population, including both highland and lowland communities, and poses a serious threat not only to the world's water resources but also to biodiversity, food security and cultural diversity. Since public services have often been concentrated in lowland areas (the principal centres of economic production), mountain regions remain among the poorest areas of the world.

Mountains provide 30 to 60 percent of freshwater in humid areas and 70 to 95 percent in more arid environments. They are also key reservoirs for plant genetic resources, offering tremendous potential for agriculture and medicine. To raise awareness of the social and economic benefits of investing in mountain areas and to trigger action on issues relating to sustainable mountain development, the United Nations (UN) has declared 2002 as the International Year of Mountains (IYM).
A series of initiatives and events is being planned to increase awareness, promote action and provide key information on mountain-related topics. Events will take place at the global, regional and national levels, with those at the national level expected to have the most significant and lasting impact. Since issues relating to freshwater involve complex interactions between highland and lowland regions, and thus the potential for conflict, the year's activities will emphasize the importance of careful management of mountain water for promoting peace. Another key objective of IYM is to promote and defend the cultural heritage of mountain communities, and to encourage governments to consider ways of giving mountain communities a greater say in decisions that affect the management of local resources.

FAO is the lead agency for IYM, working in collaboration with governments, the United Nations Environment Programme (UNEP), the United Nations Development Programme (UNDP), the
United Nations Educational, Scientific and Cultural Organization (UNESCO), other $\mathrm{UN}$ agencies and non-governmental organizations (NGOs). The Inter-agency Group on Mountains, established in 1994 to provide guidance and support to FAO in its role as task manager of Chapter 13 of Agenda 21 (Sustainable Mountain Development), also acts as an advisory group.

As part of the preparations for IYM, a new Web site has been launched, accessible from the FAO home page, in English (www.mountains2002.org), French (www.montagnes2002.org) and Spanish (www.montanas2002.org) It currently contains basic background information (including the IYM concept paper), a guide to partner organizations and events, a postcards section and an indication of new sections to be added in the months ahead.

(Source: Unasylva)

\section{Is selling non-timber forest products a dead-end for women?}

Around the world, women harvest and process non-timber forest products for sale. For the poor women of Maranhao, Brazil, extracting palm kernels from the babacu palm is their single most important source of income. The activity involves over 300000 families. Women in Botswana, India, Malaysia, and many other countries weave baskets, mats, and plates made of forest products. Women also collect or process wild nuts and fruits, medicinal plants, and palm hearts.

These activities provide employment and incomes. However, in most cases the women get low returns on their labor for each hour they spend and they typically use very rudimentary and laborious processing technologies. Many times men end up controlling most of the proceeds. Much of the work goes on at home or in nearby forests, fallows, and home gardens. That allows women to combine their income-generating activities with child raising and other domestic chores, but can also keep them politically and culturally isolated and deprive them of access to jobs and products located that are farther away.
Unless they are careful, projects designed to encourage the processing and sale of non-timber forest products can actually have a negative impact on women. When machines replaced hand stitching of sal plates in India, men displaced many of the women and left them without work. In another case from India, promotion of a formal forest management plan to promote non-timber forest product extraction also led to men taking over what had been primarily an activity for women. Similarly, women were unable to participate in a galip nut project in Papua New Guinea because the project centralized the processing activities in a town distant from the women's households.

On the other hand, when projects include specific components for women this can help them increase their political power and their ability to defend their economic interests. In Ghana, women have enthusiastically embraced the creation of leaf gatherers association that has strengthened their ability to negotiate with the forestry department and their political influence within their villages. Over 1300 women farmers in
Uganda benefited from a shea butter project designed specifically for them.

These are just a few of the interesting conclusions from "Commercialisation of Non-Timber Forest Products: Review and Analysis of Research" prepared by Roderick Neumann and Eric Hirsch for CIFOR and the FAO. The report reviews the literature on a wide variety of issues related to harvesting and processing nontimber forest products for sale. Gender aspects constitute only a small part of the topics it covers. Among other things, it looks at who benefits from these activities, whether they deplete the natural resources involved, and what governments, NGO,s and grassroots organizations can do to help people manage them better.

You can request a free electronic copy of this paper (as a large pdf file) or a hard copy from Nia Sabarniati at: n.sabaniati@cgiar.org.

David Kaimowitz, Director General Center for International Forestry Research (CIFOR) d.kaimowitz@cigiar.org 


\section{Mike Dombeck, Letter of Resignation as Chief of the US Forest Service}

Dear Secretary Veneman:

As you know, this is my final week as Chief of the United States Forest Service. I grew up on the Chequamegon National Forest along forest road 164. As a young boy, I made many trips up and down the West Fork lookout tower that was in full view from our kitchen window. As perhaps the only Chief to have actually grown up on a National Forest, it has been a distinct honor to serve with 33000 employees dedicated to caring for the land and serving people.

One hundred years ago, one of your predecessors, Secretary James Wilson, directed the Forest Service to manage public resources for "the greatest good of the greatest number in the long run." What defines the "greatest good" has changed significantly since 1904, even since 1997 when I accepted this job. Our modern industrialized society of 275 million people recognizes today that the values of open space, clean drinking water, and recreation far outstrip more traditional commodity values.

Although the mix and intensity of uses have changed significantly over the years, the multiple use mission of the Forest Service remains as important today as ever. Consider our many multiple use accomplishments of the past year. We: - Provided drinking water to approximately 60 million Americans;

- Managed about 35 million acres of wilderness;

- Performed watershed improvements on 35500 acres;

- Restored 470500 acres of wildlife and fish habitat;

- Permitted 9.3 million animal head months of livestock;

- Maintained 23000 developed recreation sites and 4300 campsites;

- Assisted 146700 woodland owners and 690 rural communities;

- Reduced hazardous fuels on 1.4 million acres;

- Developed 2500 research reports and other technical documents;

- Maintained 4.5 billion board feet of timber under contract; and

- Processed 1075 energy and bonded non-energy operations.

Early in my tenure, we faced congressional threats of "custodial funding" due to a decline in the production of commodities. Four years later after an incredibly challenging fire season and an unprecedented debate on the value of clean water and unfragmented landscapes, the overall Forest Service budget increased by 65 percent. National Forest System funding increased by 22 percent. State and Private Forestry increased by 159 percent and Research by 28 percent. I hope that you are able to continue these sorts of investments in conservation and knowledge that pay such high dividends to future generations.

As you begin your tenure as Secretary of Agriculture, I would like to share with you recommendations to help resolve specific longstanding conservation challenges as the Forest Service enters a new century of managing for "the greatest good of the greatest number in the long run."

\section{Roadless Area Protection}

I hope the Administration's intent is not to negotiate a settlement with those opposed to roadless area protection. Doing so would undermine the most extensive multi-year environmental analysis in history; a process that included over 600 public meetings and generated 1.6 million comments - the overwhelming majority of which supported protecting roadless areas. Controversy over roadless areas has persisted for decades. I hope you will withstand political pressure and not reopen this divisive debate.

Due to complexity, cost, and controversy more projects fail in roadless areas than anywhere else. Most important, not a single private land owner or corporate interest would continue to build new roads in pristine areas while saddled with a crumbling 386000 mile road system with an $\$ 8.4$ billion road maintenance backlog liability. One quarter of one percent of our nation's timber and a fraction of a fraction of our oil and gas is a small price to pay for the protection of 58.5 million acres of our children's natural resource inheritance. The long-term public interest in conserving these areas should prevail over short-term private interests.

\section{Civil Rights and Financial Management}

Much progress has been made in the areas of civil rights and financial management and accountability, but more remains to be done. The Forest Service must remain vigilant in promoting a civil rights agenda that treats employees and customers fairly and with decency and respect.

Financial management and accountability remain a significant vulnerability. Although the traditional culture of the agency does not readily accept outside assistance, I recommend your bringing in the highest quality expertise to bolster Forest Service skills and accelerate the achievement of financial and program accountability goals. With a $\$ 4$ billion budget and 35000 employees, the Forest Service is akin to a Fortune 500 company in size and complexity. It deserves comparable leadership and expertise in the arena of financial management.

\section{Old Growth}

More than any other, the old growth issue symbolizes the conflict and controversy that crippled the Forest Service for 30 years or more. Former Chief Dale Robertson called for the inventory and mapping of old growth forests more than a decade ago. It is time we completed those inventories and maps.

Moreover, it makes little sense to harvest old growth forests simply to bring their short-term economic values to market. The greatest good of these remnant forests is found through their research and study, conservation and restoration. The mark of a truly wealthy nation is not measured in acres harvested, rivers dammed, oil barrels filled, or mountaintops mined. Our maturity is most ably displayed by demonstrating mastery over ourselves. Our willingness to say, "Enough, these ancient forests cannot be improved through commodity timber production" honors our nation far more than engineering an expensive road to harvest an old growth stand.

Timber harvest remains an important function of the National Forest System. For example, thinning of brush and small diameter trees may help protect communities and restore fire-dependent ecosystems, and in the process employ thousands of people in high-quality jobs. But not if timber harvest comes at the expense of our rarest and most biologically significant old growth forests. Ensuring the conservation of old growth forests should become among the highest Forest Service priorities.

\section{Timber Trust Funds}

The incentive system that drives many Forest Service activities, despite the best 
intentions of field employees, continues to be modeled on an outdated system from a bygone era. The Forest Service helped to prompt congressional reform of a 1908 law that separates funding for rural schools and roads from timber harvest levels. If implemented as passed, this legislation can help to diminish controversy and reconnect communities to the lands and waters that sustain them.

Congress should now turn its attention to reforming the financial incentive system that promotes roadless area development and old growth harvest. The fact that timber receipts are used to pay employees and finance important programs too often pits long-term land health objectives against short-term financial considerations.

For the past two years, the Forest Service proposed that Congress make nearly $\$ 400$ million of Forest Service timberrelated trust funds (e.g., Knutson-Vandenberg, Salvage, and Brush Disposal funds) subject to public scrutiny and congressional review through the annual appropriations process. Given the increases in our budgets over the past few years, it is past time that all Forest Service programs are treated on an equal par.

\section{Wilderness}

Few congressional decisions are more forward-looking than those involving wilderness designation. We must highlight the profile of, and increase the funding for, the dwindling number of wilderness employees in the field. This helps to explain why I committed to hiring a hundred new wilderness field staff and created a separate wilderness program apart from Recreation, where Wilderness formerly resided. It is far more than a recreation resource. Wilderness is a salve to the human spirit. In an increasingly developed and urbanized society it is a tangible reminder of our pioneer heritage

As an agency, we have always had a schizophrenic relationship with wilderness. Although the Forest Service practically invented the wilderness ethic, we struggle with recommending new wilderness designations from the most biologically productive lands. Existing wilderness areas remain under threat today - from proposed mining operations under the $\mathrm{Cab}-$ inet Mountains Wilderness of Montana to chronic under funding. Remaining vigilant against these threats and recommending the expansion of wilder- ness from remote high elevation areas to old growth forests, prairie grasslands, and bottomland hardwoods would demonstrate your commitment to this enduring resource.

\section{Fire Management}

Six years ago, in the wake of a deadly fire season, Congress passed, and the President signed, the Salvage Rider. The Salvage Rider applied short-term solutions to the long-term degradation of forest ecosystem health through past management actions and fire suppression. I became Chief on the heels of this 18-month law that suspended citizen appeals and directed agency resources into timber harvest of burned and associated green trees, and inherited the rancor and gridlock it wrought.

By contrast, in the aftermath of last summer's similarly intense fire season, we crafted a bipartisan approach to protecting communities and restoring fire-dependent ecosystems not dependent on the use of traditional commercial timber sales. Our long-term solution directs protective work on the areas directly adjacent to communities most at risk, through thinning of brush and other fine fuels that are most flammable, and broader use of prescribed fire. Thousands of jobs and economic opportunities await those communities willing to perform the needed stewardship work and to use the wood fiber generated incidental to accomplishing restoration objectives. The effort will meet controversy and gridlock, however, if used to simply accelerate commercial timber harvest in the name of fire protection

\section{The 1872 Mining Law}

The General Mining Act of 1872 is the product of an era when women and many minorities could not vote, the nation was struggling through Civil War reconstruction, and St. Louis represented the western frontier to many citizens. The 1872 Mining Law confounds Forest Service efforts to balance multiple uses. Problems with the Law's antiquated royalty provisions are well known. In addition, the Law allows privatization of public lands for as little as $\$ 2.50$ to $\$ 5$ per acre. Every single use of the National Forest System: recreation, timber harvest, oil and gas development, for example, is subject to the approval or rejection of a field official for environmental or safety reasons. All but one, that is - hard rock mining.

It is Congress, not the Forest Service that must act to bring this law into a modern context. Because they have not, I recommended the segregation and withdrawal from development under the 1872 Mining Law of the Rocky Mountain Front, the Guadalupe Caves in New Mexico, portions of the biologically rich Siskiyou National Forest of Oregon, and other areas of the National Forest System. I had little choice in the matter because the anachronistic law vests anyone capable of filing a valid claim with the right to develop an area regardless of its other social or environmental values. Until Congress demonstrates the willingness to reform the outdated 1872 Mining Law, I urge you to continue to aggessively recommend the segregation and withdrawal of our most sensitive forests and grasslands from hard rock mining.

\section{Off-Highway Vehicles}

More people recreate on National Forests and Grasslands than on any other public lands. Technological innovations in motorized recreation enable people to get into more remote areas than ever before, often resulting in degraded water quality and wildlife habitat and erosion. Off-highway vehicles should remain a legitimate use of public lands where expressly allowed. We must ensure, however, that their use does not com- 
promise the integrity of the soil and water resource and wildlife habitats.

Last year, more than 100 groups petitioned me to initiate a national rulemaking regarding off-highway vehicles. I resisted in part due to other priorities. This issue, however, will not get any easier for local managers. I urge to you to ratify and implement policies that I articulated last year for the use of off-road vehicles on the National Forest System. They include:

- All off-road vehicle decisions, including those that change present levels of use, should be made through an open and public process, except where emergency closure is needed to protect public safety or forest resources.

- Motorized use should occur only on designated routes and areas. Development and use of unauthorized roads and trails should be illegal. This will require adequate signing and mapping for responsible off-road vehicle users.

If such recommendations are not implemented, the litigation and controversy that greatly reduced the timber program, will almost certainly soon haunt the Recreation Program.

\section{Private Land Conservation}

Fewer areas offer more promise for conservation and watershed restoration than private lands. Decisions by the nation's largest wood retailers to not purchase wood from endangered forests and to only sell appropriately certified wood products speak to the promise and momentum of this issue. The Forest Service State and Private and Research programs offer urban and rural residents alike voluntary options for improving management, conservation, and restoration of private lands. These programs are chronically under-funded yet entirely consistent with this Administration's stated intent to offer incentives to private land conser- vation, and should be a priority for the Department of Agriculture.

\section{Water}

Recent international studies indicate that by 2025 , two-thirds of the world's people will face water shortages. As Chief, it was my policy that watershed health and restoration serve as the overriding priority of all forest plan revisions. Fewer States demonstrate the importance of the National Forest System to drinking water than your home state, California. Although National Forests comprise only 20 percent of the State's land base, they supply nearly 50 percent of the surface runoff. Ensuring the multiple benefits of the National Forests water resource will require, among other things, a willingness to assert water rights to preserve wilderness values, providing minimum instream flows for fish, and securing bypass flows for other resources.

I recognize that short-term political imperatives run rampant in Washing- ton, DC. Please remember that the decisions you make through your tenure will have implications that last many generations. You cannot fail if you allow your loyalty to the land and to those yet to be born to take percedence over all other organizational and political fealties.

I wish you much success as Secretary of Agriculture, and hope that you receive these recommendations in the constructive manner they are intended. With clear conservation policy direction, and without micromanagement from political forces, the Forest Service is the world's finest conservation organization. Allow Forest Service employees to follow their land ethic and they will provide for "the greatest good of the greatest number in the long run."

Michael P. Dombeck Chief of the Forest Service

\section{Scientists Go Online to Discuss Threat Posed by Exotic Forest Pests}

In the past, imported diseases and insects have devastated forests and plant life throughout the world and caused millions of dollars of economic damage. This past April, scientists, along with business, government and other interested individuals from around the world gather at their keyboards for "The Risks of Exotic Forest Pests and Their Impact on Trade," a free internet presentation and discussion on how to reduce the movement of disease pests across countries.

"Some of the most deadly plant diseases have easily found their way around the world," states Cindy Ash, a plant health scientist with the American Phytopatho-

\section{FOREST AIILNCE of BiTISH COLUMBIA}

logical Society (APS), one of the sponsors of the online meeting. "Often these diseases are introduced in ways we would never think of; in wood used for packing material for example." "Since this is truly a global issue, it requires the coordinated efforts of scientists, regulators and others from around the world. In this way we can begin to develop methods for preventing the possibility of huge losses in forest plants and crops."

A panel of experts will introduce topics relating to exotic pests by posting short papers on the meeting's website, followed by a free online Internet discussion period of two weeks. Discussion will focus on how exotic pests impact forests and landscape trees, how they impact international trade, pests of current concern, methods of control, and possible guidelines, standards and regulations.

Those interested can visit the meeting's website http://exoticpests.apsnet.org/ for a preliminary program listing and to register to receive an e-mail reminder prior to the start of the online discussion.

\section{A CIF/IFC Corporate Sustaining Member}




\section{Forests for Scotland: The Scottish Forestry Strategy}

The following extract is from the Scottish Forestry Strategy launched in November 2000 by the Deputy Minister for Rural Development (the Scottish Forestry Minister) Rhona Brankin. It is the Scottish Executive's framework for taking forestry forward through the first part of the new century and beyond.

\section{Guiding Principles}

The overarching principle for the Strategy is sustainability. Scottish forestry must contribute positively to sustainable development, and meet internationally recognised standards of sustainable forest management.

The other principles are:

- integration: forestry should fit well with other rural activities in Scotland, such as agriculture, conservation, deer management, fishing, recreation and tourism; - positive value: forests and woodlands should contribute to the well-being of the people of Scotland. This contribution may be in social terms, in economic terms or in environmental terms - and there should be benefits that clearly exceed costs; - community support: forests and woodlands should be managed in ways that enjoy broad public support. Complete agreement might not always be possible, but there should be mechanisms for participation, for sharing and explaining views, and for working towards consensus;

- diversity and local distinctiveness: it is important to protect, manage and enhance the rich and varied range of woodland habitats and species, recognising that different types of forest will provide different benefits and suit different places.

\section{Strategic Directions}

The Strategy proposes five Strategic Directions for Scottish forestry.

They are:

- to maximise the value to the Scottish economy of the wood resource becoming available for harvesting over the next 20 years;

- to create a diverse forest resource of high quality that will contribute to the economic needs of Scotland throughout the 21st century and beyond;

- to ensure that forestry in Scotland makes a positive contribution to the environment;

- to create opportunities for more people to enjoy trees, woods and forests in Scotland;
- to help communities benefit from woods and forests.

\section{Priorities for Action}

The Strategy stresses that much is already happening and needs to continue. The Priorities highlighted reflect areas where more effort is needed. For each Priority, a summary is provided saying why it is a priority, the benefits of action, costs, what needs to be done, who needs to be involved, and examples of indicators of progress.

\section{To maximise the value of the wood resource}

- Improve competitiveness by developing a strong forest industries network.

- Ensure continuing investment in wood processing.

- Develop the timber transport infrastructure.

- Promote more use of timber.

- Develop products that meet market needs.

\section{To create a diverse forest resource for the future}

- Expand the area of well designed productive forest.

- Improve timber quality through following good forest practice.

- Develop more mixed forests.

- Exploit non-timber outputs and benefits of woods and forests.

- Tackle deer problems.

\section{To make a positive contribution to} the environment

- Improve management of semi-natural woodlands.

- Extend and enhance native woodlands by developing Forest Habitat Networks. - Increase the diversity of the farmed landscape.

- Aid recovery of acidified rivers and lochs and improve riparian habitat.

- Encourage alternatives to clear-felling.

- Contribute to a radical improvement in the quality and setting of urban areas.

To create opportunities for more people to enjoy trees, woods and forests

- Provide woodland recreation opportunities near towns.

- Improve availability of information about opportunities.
- Increase forestry's contribution to tourism.

\section{To help communities benefit from} woods and forests

- Create wider employment opportunities.

- Increase opportunities for community consultation.

- Provide opportunities for greater community involvement in forestry.

- Support community ownership where this will bring local benefits.

The Strategy document recognises that successful delivery of the Strategy will depend upon effective partnership and cooperation - between the private sector, the Scottish Executive, local Government and the voluntary sector; and also that inevitably, the speed of progress will depend in part on the availability of resources.

The Strategy discusses both Opportunities and Tensions, of the latter three areas are identified: impacts on other land uses; local concerns; and paying for non-market benefits. It concludes that there are no immediate or simple solutions but with proper understanding it becomes easier to work towards resolution.

The Forestry Commission will use its Corporate Plan for Scotland to set out how it intends to take the Strategy forward year by year. Other Departments and Agencies of the Scottish Executive will take account of the Strategy when developing policies that may have an impact on forestry. A review of the Woodland Grant Scheme and Farm Woodland Premium Scheme will be undertaken to ensure that they are well aligned with both the Forestry and Agriculture Strategies.

This is taken from the full document (Scottish Executive publication number SE/2000/199) which can be obtained from the Forestry Commission - National Office for Scotland, 231 Corstorphine Road, Edinburgh EH12 7AT (Telephone: 01313146144 or e-mail: john.cummings@forestry.gsi.gov.uk). Alternatively, the document is also available on the Forestry Commission website (www.forestry.gov.uk).

Source: Scottish Forestry, Vol. 55, No 12001 ) 


\section{Weyerhaeuser Urges Use of Envoys in Lumber War}

North America's largest lumber producer, Weyerhaeuser Co., is urging the Canadian and US governments to appoint special envoys in a bid to resolve a potentially costly trade dispute between the two countries.

Having stayed neutral for months as the softwood lumber dispute heated up, Weyerhaeuser broke its silence saying in a letter to Prime Minister Jean Chrétien and US President George W. Bush that an envoy process is the "most likely means of achieving a fair, long-term solutions for all parties."

Steven Rogel, Weyerhaeuser president, is not the only US industry leader in the United States who sees the need to prevent the US coalition from placing duties on lumber imports.

Some of the biggest lumber buyers in the United States argued that their customers want Canadian softwood lumber irrespective of price.

"We require a steady supply of Canadian lumber to meet the needs of our customers," said Stephen Conwell, the executive who heads global lumber purchases for Home Depot." "Sales of Canadian lumber is not displacing sales of domestic (US) lumber because the types meet different needs," he said in a claim echoed by scores of dealers and homebuilders.

Source: Globe \& Mail

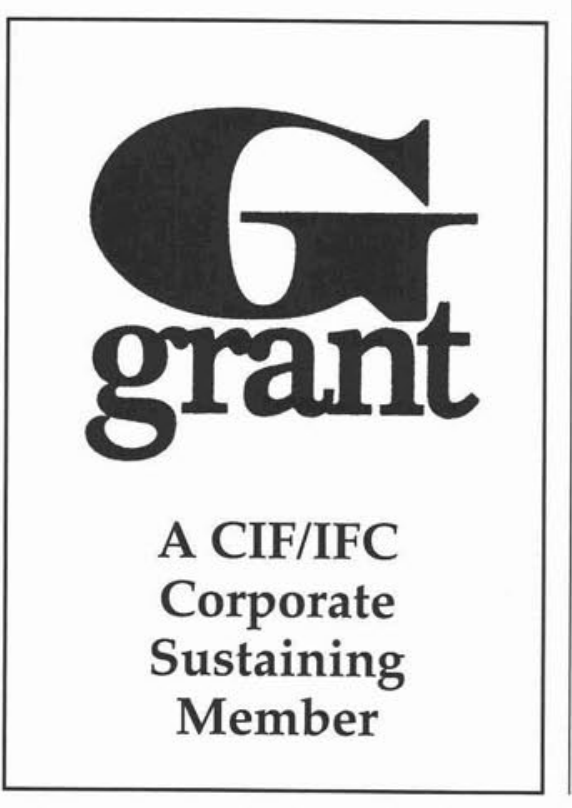

\section{Exploring the Value of Urban Forest Products}

A new study based in Baltimore, Maryland, United States, has reported that many urban residents collect, use and even sell urban non-timber forest products (NTFP) such as fruits, nuts, mushrooms, medicinal plants, vines, seedlings and decorative greens and cones. These products provide important economic, nutritional, recreational, educational and cultural benefits to residents, and represent an often overlooked value of the urban forest.

Foresters and researchers have long documented a number of benefits provided by urban trees and forests, from pollution control to wildlife habitat to beauty. But, until recently, scant attention had been paid to the role and value of products from the urban forest. In an effort to overcome this gap in knowledge, Community Resources, a regional non-profit organization in the United States, undertook a detailed study during 1998 and 1999, with support from the National Urban and Community Forestry Advisory Council. In this study, Community Resources staff conducted more than 100 interviews, field observations and market visits to uncover the uses, benefits and values - both monetary and personal - of urban NTFPs.

The project aims to help environmental professionals, urban land managers and policy-makers gain a better understanding of the potential importance of urban forest products. This will lead to better policies and management strategies that promote sustainable urban forest use.

The key findings were:

- More than 103 products are currently collected by individuals and organizations in Baltimore City, including: edible prod-

\section{South Africa chosen to host Earth Summit 2002}

The second Committee of the UN General Assembly on Rio +10 has announced that the conference marking the tenth anniversary of the United Nations Conference on Environment and Development (Rio de Janeiro, Brazil, 1992) will be entitled "World Summit on Sustainable Development". The meeting, which is expected to set the agenda for sustainable development and the environment for the following ten years, will be held in Johannesburg, South Africa in 2002.

South African officials hope that holding this major conference in South Africa will raise the prominence of issues and ucts ( 43 percent), medicinal products ( 8 percent), horticultural or nursery products (31 percent) and craft and decorative products (18 percent).

- Collectors include public agencies, non-profit organizations and a wide diversity of individuals.

- Products are collected from street trees, park trees, house gardens, vacant lots, roadsides and forests.

- Direct net value was calculated for 60 products.

- The value of products ranges from about US\$0.70/kg for pokeweed (Phytolacca americana) to more than $\$ 22 / \mathrm{kg}$ for some seeds and woodland mushrooms.

- Net annual per tree values range from $\$ 4 / y e a r$ for an average mulberry tree to more than $\$ 103$ per year for mature Chinese chestnut, apricot and peach trees. - Urban forest product collection also provides important educational, nutritional, cultural and recreational benefits, which were not included in the dollar values above.

- Key issues surrounding urban NTFP collection include the lack of collector empowerment, potential conflicts between collectors and property owners, health and toxicity issues, and sustainable harvest and ecological impact issues.

Contact: Mr. Paul Jahnige, Community Resources, 4900 Wetheredsville Road, Baltimore, MD 21207, USA. Fax: +1410448 0874; e-mail: info@community resources.org; www.communityresources. org/ntfp.htm.

Source: Non-Wood News

debates related to forest protection, clean water and other crucial environmental and sustainability issues on African agendas.

The tenth session of the Commission on Sustainable Development (CSD10) will function as the preparatory committee for the World Summit on Sustainable Development. Four preparatory committee sessions will be held: from 30 April to 2 May 2001, in late January 2002 and in mid-March 2002, all in New York; and in mid-May 2002, in Indonesia. This last preparatory session will be at the ministerial level.

Source: Unasylva 